\title{
PENGELOLAAN RETRIBUSI IZIN MENDIRIKAN BANGUNAN DALAM MENINGKATKAN PENDAPATAN ASLI DAERAH DI DINAS PENANAMAN MODAL DAN PELAYANAN TERPADU SATU PINTU KABUPATEN SUMEDANG PROVINSI JAWA BARAT (Studi pada Kecamatan Jatinangor Kabupaten Sumedang Provinsi Jawa Barat)
}

\author{
Oleh \\ Lu'luatu Zakiyah ${ }^{1}$, \\ Khasan Effendy ${ }^{2}$, Kusworo ${ }^{3}$ \\ ${ }^{1)}$ Program Magister Terapan Studi Pemerintahan Institut Pemerintahan Dalam Negeri \\ zluluatu@gmail.com \\ ${ }^{2,3)}$ Institut Pemerintahan Dalam Negeri
}

\begin{abstract}
$L$ evy IMB will hit the target well when management is running well too. This has been stipulated in the Sumedang Regency Regional Regulation Number 5 of 2011 concerning Certain Permits Retribution. Jatinangor Subdistrict designated as a Provincial Strategic Area should be able to show an increase in building permits levies, but this is not in line with the facts.

This study aims to determine and analyze the IMB Levy Management that has been implemented, to know and analyze the obstacles encountered in its implementation and to know and analyze the right ideal strategy or concept in the management of IMB Levies. The theory used is the management theory proposed by Hasibuan (2008), namely the management function: (1) Planning, (2) Organizing, (3) Commanding, (4) Coordinating, (5) Controlling (Supervision). This research also uses descriptive qualitative method and data collection techniques using interviews, observation, and documentation.
\end{abstract}

The results showed that the DPMPTSP strategy in managing the building permits levy was not optimal, due to the fact that the community was not prepared to apply the online building permit registration system. Apart from that, the socialization provided by the government to the community is minimal, which is why the target of the realization of building permits levies has always decreased in the past three years. Therefore, in this study the authors convey several strategies in the management of building permits levies, namely: Bleaching building permits and improving supervision. Make use of good information media to increase the number of mandatory IMB. Take advantage of the area, because it is an educational strategic area in increasing regional development.

Keywords: management, retribution, building permit.

\section{ABSTRAK}

$\mathrm{R}$ etribusi IMB akan mencapai target dengan baik apabila pengelolaannya dijalankan dengan baik pula. Hal ini telah ditetapkan dalam Peraturan Daerah Kabupaten Sumedang No. 5 Tahun 2011 tentang Retribusi Perizinan Tertentu. Kecamatan Jatinangor ditetapkan sebagai 
Kawasan Strategis Provinsi seharusnya dapat menunjukkan peningkatan dalam Retribusi Izin Mendirikan Bangunan, namun hal ini tidak sejalan dengan fakta yang ada.

Penelitian ini bertujuan untuk mengetahui dan menganalisis Pengelolaan Retribusi Izin Mendirikan Bangunan yang telah dilaksanakan, mengetahui dan menganalisis kendalakendala yang ditemui dalam pelaksanaannya serta mengetahui dan menganalisis strategi atau konsep ideal yang tepat dalam pengelolaan Retribusi IMB. Teori yang digunakan adalah teori pengelolaan yang dikemukakan oleh Hasibuan (2008) yaitu fungsi manajemen: (1) Planning (Perencanaan), (2) Organizing (pengorganisasian), (3) Commanding (Pengarahan), (4) Coordinating (Pengoordinasian), (5) Controlling (Pengawasan). Penelitian ini juga menggunakan Metode kualitatif deskriptif serta teknik pengumpulan data dengan menggunakan wawancara, observasi, dan dokumentasi.

Hasil penelitian menunjukkan bahwa strategi DPMPTSP dalam pengelolaan Retribusi Izin Mendirikan Bangunan belum optimal, karena ditemukannya ketidaksiapan masyarakat akan penerapan sistem pendaftaran Izin Mendirikan Bangunan secara online. Selain itu pun sosialisasi yang diberikan oleh pemerintah kepada masyarakat sangatlah minim yang menyebabkan mengapa target realisasi penerimaan retribusi Izin Mendirikan Bangunan dalam tiga tahun ke belakang selalu menurun. Oleh karena itu, dalam penelitian ini penulis menyampaikan beberapa strategi dalam Pengelolaan Retribusi Izin Mendirikan Bangunan yaitu: Pemutihan Izin Mendirikan Bangunan serta Meningkatkan Pengawasan. Memanfaatkan media informasi yang baik untuk meningkatkan jumlah wajib IMB. Memanfaatkan wilayah, karena sebagai Kawasan Strategis Pendidikan dalam meningkatkan pembangunan daerah. Serta meningkatkan sosialisasi agar masyarakat patuh dan wajib IMB.

Kata kunci: pengelolaan, retribusi, izin mendirikan bangunan.

\section{PENDAHULUAN}

$\mathrm{P}$ endapatan asli daerah atau biasa disebut PAD adalah pendapatan yang bersumber dan dipungut sendiri oleh pemerintah daerah. Sumber PAD ini terdiri dari: pajak daerah, retribusi daerah, laba dari badan usaha milik daerah (BUMD), dan pendapatan asli daerah lainnya yang sah. Berbicara mengenai retribusi daerah, tidak dapat dipungkiri bahwa salah satu PAD yang terbesar adalah dari retribusi. Retribusi sendiri selalu dikaitkan dengan yang namanya PAD karena retribusi daerah, yang selanjutnya disebut retribusi, adalah pungutan daerah sebagai pembayaran atas jasa atau pemberian izin tertentu yang khusus disediakan dan/atau diberikan oleh Pemerintahan Daerah untuk kepentingan orang pribadi atau badan.

Kegiatan perizinan khususnya Izin Mendirikan Bangunan (IMB) merupakan salah satu PAD yang bertujuan agar menciptakan suatu kondisi bahwa kegiatan tersebut sesuai dengan peruntukannya dalam rangka pelayanan terhadap masyarakat dan pembangunan. Sehingga retribusi IMB sangat diperlukan untuk mengoptimalisasikan PAD agar pemenuhan kebutuhan daerah dapat terpenuhi secara maksimal.

Dalam Peraturan Daerah Kabupaten Sumedang No. 5 Tahun 2011 tentang Retribusi Perizinan Tertentu bahwa Retribusi Daerah merupakan salah satu sumber pendapatan daerah yang penting guna membiayai penyelenggaraan Pemerintahan Daerah dan Pembangunan Daerah untuk memantapkan Otonomi Daerah yang luas, nyata, dan tanggung jawab.

Kabupaten Sumedang khususnya di Kecamatan Jatinangor adalah salah satu yang menginvestasikan pendapatannya melalui retribusi dari IMB. PAD di Kecamatan Jatinangor merupakan penyumbang PAD terbesar di Kabupaten Sumedang, karena ini 
terlihat dari beberapa faktor salah satunya yaitu Kecamatan Jatinangor merupakan salah satu kawasan khusus yang berada di Kabupaten Sumedang Provinsi Jawa Barat.

Menurut Rencana Tata Ruang Wilayah Provinsi Jawa Barat Tahun 2009-2029, Kecamatan Jatinangor ditetapkan sebagai pusat pendidikan tinggi Kawasan Strategis Provinsi (KSP) karena mempunyai pengaruh sangat penting dalam aspek pendidikan yang secara tidak langsung memengaruhi aspek ekonomi, lingkungan, sosial budaya dan pendayagunaan sumber daya alam. Hal inilah yang menjadi dasar dalam menetapkan kawasan di Kecamatan Jatinangor sebagai salah satu kawasan khusus. Pemerintah Daerah mengharapkan dengan adanya kawasan strategis pendidikan tinggi ini dapat meningkatkan penyelenggaraan pendidikan tinggi nasional yang lebih baik.

Perubahan yang semakin pesat di kawasan ini tidak diimbangi dengan peningkatan pelayanan publik di kawasan pendidikan tinggi ini. Banyak permasalahan pelayanan publik yang dapat ditemui di kawasan ini. Beberapa permasalahan di antaranya terkait pendataan kependudukan bagi para pendatang, baik yang menjadi mahasiswa maupun pekerja masih belum terdatadenganbaik.Permasalahankeamanan masih sering ditemui, misalnya pencurian kendaraan bermotor di lingkungan rumah kos. Permasalahan lalu lintas yaitu adanya kepadatan dan kemacetan mengakibatkan ketidaknyamanan dalam berlalu lintas. Pengelolaan sampah yang tidak baik juga berdampak pada polusi udara, bau tidak sedap dan mengganggu kesehatan, dan masih banyak lagi permasalahan pelayanan publik di kawasan ini.

Sampai saat ini pun masih dijumpainya beberapa fenomena ditemukannya bangunan yang tidak memiliki IMB yang tidak sesuai dengan peruntukan kawasan dan rencana tata ruang wilayah di Kecamatan Jatinangor dan tidak adanya tindakan dan upaya pengendalian yang dilakukan oleh pemerintah setempat. Sehingga kepatuhan masyarakat akan pentingnya memiliki IMB di Kecamatan Jatinangor masih sangat rendah terhadap bangunan yang dimilikinya.

Untuk membuktikan permasalahan tersebut, penulis mengambil sampel dari data primer. Sampel yang diambil adalah 10 bangunan gedung yang berada di Kecamatan Jatinangor, lalu penulis wawancarai langsung pada pemilik bangunan gedung tersebut bahwa apakah mereka mempunyai IMB atau tidak. Berikut merupakan data primer yang penulis dapatkan dari lapangan.

Tabel 1 Jawaban sepuluh responden tentang kepemilikan Izin Mendirikan Bangunan (IMB)

\begin{tabular}{|c|c|c|}
\hline No & Nama & Keterangan \\
\hline 1 & Responden 1 Bapak “T” & Sudah Punya IMB \\
\hline 2 & Responden 2 Ibu "A" & Sudah Punya IMB \\
\hline 3 & Responden 3 Ibu “G” & Sudah Punya IMB \\
\hline 4 & Responden 4 Bapak "A" & Belum Punya IMB \\
\hline 5 & Responden 5 Bapak “D” & Belum Punya IMB \\
\hline 6 & Responden 6 Bapak "K" & Belum Punya IMB \\
\hline 7 & Responden 7 Bapak “M” & Belum Punya IMB \\
\hline 8 & Responden 8 Bapak "H" & Belum Punya IMB \\
\hline 9 & Responden 9 Bapak "N" & Belum Punya IMB \\
\hline 10 & Responden 10 Bapak “T” & Belum Punya IMB \\
\hline & $\begin{array}{l}\text { Responden yang sudah } \\
\text { memiliki IMB sebesar } \\
30 \% \text {, sedangkan yang } \\
\text { belum mempunyai IMB } \\
\text { sebesar } 70 \% \text {. }\end{array}$ & \\
\hline
\end{tabular}

Sumber: Diolah Penulis, 2020

Dari perbandingan sampel diatas penulis simpulkan bahwa sebagian masyarakat yang tidak mempunyai IMB lebih banyak jumlahnya dibandingkan dengan yang sudah memiliki IMB. Ini membuktikan bahwa kesadaran masyarakat akan pentingnya mempunyai IMB itu masih kurang, sehingga ini menjadi salah satu penyebab mengapa retribusi dalam bidang pelayanan IMB belum mencapai target. 
Dengan berbagai permasalahan pelayanan publik tersebut dan adanya tuntutan oleh pendidikan masyarakat, maka permasalahan pelayanan publik di kawasan Kecamatan Jatinangor ini menjadi hal yang menarik untuk dikaji. Sejauh mana tindakan Pemerintah Daerah dalam memberikan pelayanan publik di kawasan ini dan bagaimana pelayanan publik yang seharusnya ada di Kecamatan Jatinangor sebagai Kawasan Pendidikan Tinggi.

Izin Mendirikan Bangunan sendiri dikeluarkan oleh pemerintah daerah setempat dalam Peraturan Daerah Kabupaten Sumedang No. 15 Tahun 2011 tentang Bangunan Gedung. Namun di Kecamatan Jatinangor sendiri diduga belum semua bangunan gedung mempunyai surat IMB (SIMB) karena dari pihak Kecamatan Jatinangor sendiri belum ada operasi khusus untuk mendata bangunan gedung mana saja yang sudah mempunyai IMB. Kemudian, rendahnya keinginan masyarakat untuk mengurus IMB dari setiap bangunan yang didirikan dapat dilihat berdasarkan data dan jumlah IMB yang diterbitkan oleh Dinas Penanaman Modal Pelayanan Terpadu Satu Pintu Kabupaten Sumedang pada tabel 2.

Berdasarkan tabel 2, pada 2017 jumlah KK yang ada di Kecamatan Jatinangor sebanyak 25.349 KK dengan jumlah pemohon 661 orang dan menghasilkan pendapatan retribusi IMB sebesar Rp284.200.000.000, sedangkan pada 2018 jumlah KK di Kecamatan Jatinangor naik berjumlah $25.721 \mathrm{KK}$ dengan pendapatan retribusi Rp26.875.000.150. Terakhir, pada 2019 jumlah KK di Kecamatan Jatinangor makin meningkat sebesar $25.987 \mathrm{KK}$ dan jumlah pemohon IMB 430 orang dengan pendapatan retribusinya Rp4.484.000.000. Dalam tiga tahun terakhir, apabila penulis bandingkan terdapat adanya kenaikan jumlah kepala keluarga namun tidak diiringi pula dengan kenaikan jumlah pemohon IMB maupun hasil pendapatan retribusinya juga.

Hal ini membuktikan bahwa jumlah bangunan yang sudah memiliki IMB di Kecamatan Jatinangor masih kurang jika dibandingkan dengan jumlah keseluruhan keluarga yang ada di Kecamatan Jatinangor. Dari jumlah banyaknya kepala keluarga yang ada, hanya beberapa bangunan yang sudah memiliki IMB. Dalam hal ini, menunjukkan pula kesadaran masyarakat akan pentingnya memiliki IMB untuk bangunan yang mereka dirikan masih kurang. Adanya fenomena ini menyebabkan pemohonan IMB ternyata masih belum optimal sehingga akan berdampak pada pemanfaatan Retribusi serta belum terinventarisasi dengan baik IMB di Kecamatan Jatinangor.

Selain itu juga ditemui kendala terkait proses dalam permohonan IMB di mana ditemukannya calo untuk membantu para pemohon yang tidak paham akan tata cara mendaftar IMB yang mengakibatkan para pemohon harus membayar dua kali lipat untuk calo tersebut. Hal ini juga tentunya membuat pihak pemungut retribusi yaitu Dinas Penanaman Modal Pelayanan Terpadu Satu Pintu (DPMPTSP) juga selaku pihak pengelola dari hasil pungutan retribusi IMB mengalami kendala dalam pungutan dan pengelolaan retribusi tersebut.

Tabel 2 Data Izin Mendirikan Bangunan (IMB) Kecamatan Jatinangor

\begin{tabular}{ccccc}
\hline No & Tahun & Jumlah Keluarga & Jumlah Pemohon IMB & Jumlah Retribusi (Rp) \\
\hline 1 & 2017 & $25.349 \mathrm{KK}$ & 661 & 284.200 .000 .000 \\
2 & 2018 & $25.721 \mathrm{KK}$ & 441 & 26.875 .000 .150 \\
3 & 2019 & $25.987 \mathrm{KK}$ & 430 & 4.484 .000 .000 \\
\hline
\end{tabular}

Sumber: DPMPTSP Kabupaten Sumedang (2020) 
Tabel 3 Pendapatan Asli Daerah Kabupaten Sumedang

\begin{tabular}{cccc}
\hline No. & Tahun & Target PAD (Rp) & Realisasi PAD (Rp) \\
\hline 1 & 2017 & 402.302 .926 .879 .29 & $523.547 .667 .603,07$ \\
2 & 2018 & $464.361 .703 .852,86$ & $432.196 .794 .863,30$ \\
3 & 2019 & $461.034 .212 .549,29$ & $530.215 .807 .457,00$ \\
\hline
\end{tabular}

Sumber: Bappenda Kabupaten Sumedang (2019)

Data menunjukkan bahwa Pendapatan Kabupaten Sumedang dari tahun tahun 2017 sudah melampaui target. Sedangkan, pada 2018 mengalami penurunan pendapatan dan tidak memenuhi target, namun pada 2019 justru naik lagi jumlahnya sehingga melampaui target. Jelaslah bahwasanya PAD Kabupaten Sumedang mengalami peningkatan naik turun yang berubah-ubah. Berdasarkan data di atas, dapat dilihat juga bahwa realisasi PAD Kabupaten Sumedang tahun 2017, tahun 2018 dan tahun 2019 menunjukkan bahwa Pemerintah Kabupaten Sumedang telah bekerja dengan maksimal dalam menjalankan tugasnya untuk meningkatkan PAD Kabupaten Sumedang.

Tabel 4 Pendapatan Asli Daerah Kabupaten Sumedang Bidang Pelayanan Izin Mendirikan Bangunan (IMB)

\begin{tabular}{cccc}
\hline No. & Tahun & Target IMB & Realisasi IMB \\
\hline 1 & 2017 & $6.308 .120 .000,00$ & $5.832 .841 .013,00$ \\
2 & 2018 & $5.376 .480 .000,00$ & $4.419 .685 .730,00$ \\
3 & 2019 & $5.376 .480 .000,00$ & $4.724 .770 .693,00$ \\
\hline \multicolumn{3}{l}{ Sumber: DPMPTSP Kabupaten Sumedang (2019) }
\end{tabular}

Selanjutnya dari tabel 3. data yang menunjukkan PAD dalam bidang pelayanan perizinan dari tahun 2017, tahun 2018, dan tahun 2019 juga tidak semuanya melampaui target. Ini menunjukkan bahwa PAD Kabupaten Sumedang belum mencapai target yang telah ditetapkan, padahal dalam realisasinya Kabupaten Sumedang cukup mendapatkan banyak dari hasil retribusi IMB.

Dari berbagai fenomena yang ada, penulis tertarik untuk mengambil latar belakang masalah ini karena Kecamatan Jatinangor yang ditetapkan sebagai Kawasan Strategis Provinsi mengakibatkan perkembangan wilayah yang berada di Kecamatan Jatinangor sangat pesat, namun pengaturan tata ruangnya masih belum cukup bisa dikatakan dari kata tertib. Padahal, Kecamatan Jatinangor merupakan salah satu penyumbang PAD terbesar di Kabupaten Sumedang.
Berdasarkan latar belakang masalah tersebut penulis merumuskan permasalahan Bagaimana Pengelolaan Retribusi IMB, apa saja faktor pendukung dan penghambat dalam pengelolaan Retribusi IMB, serta bagaimana strategi pengelolaan retribusi IMB dalam upaya meningkatkan PAD di Kecamatan Jatinangor Kabupaten Sumedang.

Berdasarkan Rumusan masalah di atas, tujuan dari penelitian ini adalah untuk menganalisis Bagaimana Pengelolaan Retribusi IMB, faktor pendukung dan penghambat serta menganalisis bagaimana strategi pengelolaan retribusi IMB dalam upaya meningkatkan PAD di Kecamatan Jatinangor Kabupaten Sumedang.

\section{METODE PENELITIAN}

Dalam penelitian ini, metode penelitian yang digunakan oleh penulis adalah 
penelitian kualitatif dengan pendekatan deskriptif. Sugiyono (2013) memaparkan bahwa metode penelitian kualitatif adalah metode penelitian yang berlandaskan pada filsafat postpositivisme, digunakan untuk meneliti pada kondisi objek yang alamiah, (sebagai lawannya adalah eksperimen), analisis dan data bersifat induktif/kualitatif, dan hasil penelitian kualitatif lebih menekankan makna dari pada generalisasi. Moleong (2014: 6) juga menjelaskan bahwa "penelitian kualitatif merupakan penelitian yang bermaksud untuk memahami fenomena tentang apa yang di alami oleh subjek penelitian misalnya perilaku, persepsi, motivasi, tindakan dan lain-lain".

Penelitian ini menggunakan metode wawancara, maka instrumen penelitiannya adalah menggunakan pedoman wawancara sehingga penulis melakukan wawancara serta pencatatan terhadap data yang diperlukan terkait Pengelolaan Retribusi IMB dalam meningkatkan PAD di Dinas Penanaman Modal dan Pelayanan Terpadu Satu Pintu Kabupaten Sumedang Provinsi Jawa Barat (Studi Pada Kecamatan Jatinangor Kabupaten Sumedang Provinsi Jawa Barat).

Jumlah informan yang dipilih sebagai sampel pada penelitian ini menggunakan teknik purposif, yaitu memilih orang-orang yang dianggap mengetahui dan mampu memberikan informasi yang relevan dengan fokus permasalahan yang akan diteliti oleh penulis. Hal ini sesuai dengan pendapat Sugiyono (2012: 219) yang menyatakan bahwa purposive sampling adalah teknik Penentuan sampel dengan pertimbangan tertentu.

Sebagai suatu proses interaksi dan komunikasi dalam penelitian ini digunakanlah teknik pengumpulan data yang langsung diambil di lapangan. Selain itu peneliti juga melakukan tahapan yaitu wawancara, dokumentasi, observasi lapangan. Setelah ketiga langkah tersebut dilakukan maka selanjutnya dilakukan
Analisis SWOT terhadap data yang diperoleh berdasarkan Rangkuti (2014: 83) dan kemudian dilakukan pengembangan beberapa ukuran tentang bagaimana strategisnya isu berdasarkan Bryson (2008: 182).

Sugiyono (2014: 245) memaparkan "analisis data dalam penelitian kualitatif dilakukan sejak sebelum memasuki lapangan, selama di lapangan dan setelah di lapangan". Adapun langkah-langkah teknik analisis data dalam penelitian adalah dengan menggunakan model interaktif sebagaimana yang dikemukakan oleh Miles dalam Sugiyono (2014: 246), teknik analisis data yaitu "data reduction, data displai, conclusion/verification".

\section{HASIL PENELITIAN DAN PEMBAHASAN}

\section{Planning (Perencanaan)}

Perencanaan adalah kegiatan yang pertama-tama harus dilaksanakan sebelum aktivitas lainnya dilakukan. Penerapan fungsi manajemen dalam pengelolaan retribusi IMB di Kecamatan Jatinangor sudah dilaksanakan meskipun terdapat beberapa ketidaksesuaian dengan perencanaan yang diharapkan.

Menurut Peraturan Bupati Sumedang No. 30 Tahun 2017 tentang Pendelegasian sebagian kewenangan di bidang perizinan dan Non-perizinan dari Bupati kepada Kepala Dinas Penanaman Modal Dan Pelayanan Terpadu Satu Pintu, Pelayanan IMB sudah tidak lagi ada di Kecamatan seluruh Kabupaten Sumedang. Semenjak itu, DPMPTSP membuat sebuah Aplikasi SI ICE Mandiri atau Sistem Cetak Mandiri yang bertujuan untuk memudahkan masyarakat dalam mengajukan IMB. Menurut Syarif Effendi selaku Camat Jatinangor:

"Sejak tahun 2017 kalau tidak salah peran kecamatan tidak secara langsung memungut retribusi IMB. Sejak 1 Januari 2017 sudah dilimpahkan wewenang jadi 
peran kecamatan hanya melegalisasi dan memberikan rekomendasi. Jadi baik penerbitan IMB sendiri maupun pengelolaan retribusi IMB sendiri langsung disetor ke Pemda kas daerah dan alhamdulillah sudah ada program baru si ICE Mandiri sistem informasi cetak sendiri secara online, jadi si pemohon sudah dapat persetujuan dari tetangga, izin lingkungan dan mendapatkan legalisasi oleh kepala desa dan direkomendasikan oleh camat, jadi dia mengunggah (upload) sendiri di aplikasi kemudian termasuk berapa perhitungan retribusi yang harus disetorkan itu nanti keluar. Jadi harus punya akun sendiri, hitungannya itu 14 hari bisa terbit setelah itu diberi pasword agar bisa cetak sendiri." (5 Agustus 2020)

Jadi, berdasarkan tanggapan Syarif Effendi bahwa Kecamatan Jatinangor dan kecamatan lainnya yang ada di seluruh Kabupaten Sumedang sudah tidak lagi bisa membuat IMB di kecamatan masing-masing, namun hanya dapat meminta rekomendasi saja. Selain itu, masyarakat dapat membuat IMB melalui aplikasi online SI ICE Mandiri yang telah dibuat oleh DPMPTSP.

SI ICE Mandiri ini merupakan sebuah sistem informasi pelayanan perizinan dan non-perizinan yang memungkinkan pemohon dapat mengunduh SK perizinan dan mencetaknya secara mandiri. Aplikasi ini berbasis online sehingga masyarakat dapat melakukan pengajuan perizinan dengan memanfaatkan teknologi internet. Sistem informasi ini sangat cocok digunakan di DPMPTSP (Dinas Penanaman Modal dan Pelayanan Terpadu Satu Pintu) di Kabupaten/Kota. Sistem informasi ini dilengkapi dengan kemampuan-kemampuan yang dapat memudahkan baik dari sisi pemohon (masyarakat) maupun dari sisi petugas DPMPTSP.
Untuk memudahkan masyarakat pun SI ICE Mandiri menyediakan berupa SK dengan Digital Signature atau tanda tangan digital, secara garis besar Tanda Tangan Digital adalah sebuah skema matematis yang memiliki keunikan dalam mengidentifikasikan seorang (subjek hukum) di dunia digital. Tanda tangan digital ini sebagai bentuk keabsahan atau legalitas dan keamanan, SK perizinan dilengkapi dengan QRCODE dan tanda tangan Digital yang terverifikasi oleh root ca KOMINFO.

Sementara itu, dalam Peraturan Pemerintah Republik Indonesia No. 24 Tahun 2018 tentang Pelayanan Perizinan Berusaha Terintegrasi Secara Elektronik Tanda Tangan Elektronik adalah tanda tangan yang terdiri atas Informasi Elektronik yang dilekatkan, terasosiasi atau terkait dengan Informasi Elektronik lainnya yang digunakan sebagai alat verifikasi dan autentikasi.

Selanjutnya, apabila pemohon sudah mendapatkan tanda tangan elektronik, maka pemohon tersebut akan mendapatkan sebuah izin dalam berupa dokumen elektronik. Dokumen Elektronik adalah setiap informasi elektronik yang dibuat, diteruskan, dikirimkan, diterima, atau disimpan dalam bentuk analog, digital, elektromagnetik, optikal, atau sejenisnya, yang dapat dilihat, ditampilkan, dan/ atau didengar melalui komputer atau sistem elektronik, termasuk tetapi tidak terbatas pada tulisan, suara, gambar, peta, rancangan, foto atau sejenisnya, huruf, tanda, angka, kode akses, simbol atau perforasi yang memiliki makna atau arti atau dapat dipahami oleh orang yang mampu memahaminya.

Namun, tidak dapat dipungkiri bahwa masih terdapat sebagian masyarakat yang mengaku tidak terlalu paham akan penggunaan aplikasi online tersebut dikarenakan masih adanya gagap teknologi pada sebagian masyarakat. 


\section{Organizing (Pengorganisasian)}

Pengorganisasian adalah pengelompokan aktivitas yang akan dilakukan atau pendistribusian tugas dan fungsi kepada setiap individu yang ada dalam organisasi. Karena, dengan mengorganisasikan dimaksudkan pengelompokan kegiatan yang diperlukan yakni penetapan susunan organisasi serta tugas dan fungsi-fungsi dari setiap unit yang ada dalam organisasi.

Di Kecamatan Jatinangor sendiri, ditemukan belum idealnya penentuan tugas dan pekerjaan pada pengelola retribusi IMB karena terbatasnya sumber daya manusia. Hal ini pun sejalan dengan pendapat Budilatif selaku Staf kasi Pelayanan umum di Kecamatan Jatinangor sebagai berikut.

"Dari SDM sendiri kita kekurangan staf, dari semua yang memeriksa saya, menghitung saya, kalau pemohon di sini tidak begitu banyak, yang banyak konsultasi soal IMB mengenai masalah persyaratan apa saja. Kadang 1 bulan 15-20 pemohon, tapi kalau pemohon yang gagal belum bisa diproses." (15 Agustus 2020)

Dalam wawancara tersebut, Kania selaku Staf Pengelola Retribusi IMB di DPMPTSP pun menambahkan pendapat yang sama bahwa:

"Terus terang, memang kurang di sini, kadang suka aja ada staf yang kurang mengerti apa tupoksinya sendiri yang akibatnya saya juga ikut membantu dan mengerjakan pekerjaan double." (14 Agustus 2020)

Dari wawancara tersebut sumber daya manusia yang ada terlihat kurang terspesialisasi dengan baik yang mengakibatkan sulitnya untuk meningkatkan kualitas sumber daya di DPMPTSP tersebut padahal fakta dalam lapangan membuktikan bahwa pemohon IMB di Kecamatan Jatinangor sangat tinggi di antara kecamatankecamatan yang lain.

\section{Commanding (Pengarahan)}

Fungsi manajemen yang berhubungan dengan usaha memberi bimbingan, saransaran atau memberi sebuah instruksi kepada bawahan tersebut, agar tugas dapat dilaksanakan dengan baik benar-benar kepada tujuan yang telah ditetapkan.

Dalam pengarahan yang diberikan oleh DPMPTSP kepada masyarakat seharusnya diberikannya sosialisasi oleh pihak instansi kepada masyarakat. Namun, ditemukan bahwa ada beberapa masyarakat salah satunya Ibu Ade selaku warga Jatinangor yang mengaku belum pernah mendapatkan sosialisasi tersebut. Hal itu disampaikan ketika ditanyai apakah pernah mendapatkan sosialisasi dari pihak pemerintah daerah yaitu:

"Saya kurang tahu, prosedurnya saja kadang saya masih bingung juga sih tapi ya kalau bangunan harus ada IMB-nya sih saya tahu." (5 Oktober 2020)

Namun, berbeda dengan halnya dengan Heri yang berpendapat bahwa:

"Kayanya belum, saya belum pernah dapat sosialisasi dari lembaga ini terkait dengan cara pengurusan IMB. Selama ini sih, saya tahu pengurusan ini dari teman saya yang sudah berpengalaman mengurus IMB." (5 Oktober 2020)

Hal ini sejalan dengan pendapat Diki selaku Kepala Seksi Penatausahaan Perizinan di DPMPTSP Kabupaten Sumedang sebagai berikut.

"Sosialisasi terkait dengan sistem door to door kita belum ke arah sana. Tapi kita sosialisasi berupa ke kecamatan berupa sistem pelayanan masih online itu sudah tapi untuk pemaparan seperti menerangkan ke tiap-tiap desa. belum ke arah situ karena keterbatasan anggaran dan keterbatasan SDM juga. Kita gak mungkin ada 227 Desa disumedang didatangkan satu-satu. Tapi dari segi sosialisasi dari segi itu belum ke situ, 
tetapi sosialisasi secara virtual, secara apa sosial media dan digital melalui web. Kalau mau liat tinggal buka perizinan sumedang pasti ada di situ, tapi kadang gak banyak orang tau karena masih banyak orang yang konvensional masih suka nanya-nanya ke orang-orang padahal semua bisa lihat di google." (14 Agustus 2020)

Berdasarkan hasil wawancara di atas, dapat disimpulkan bahwa sosialisasi yang harusnya diadakan oleh pemerintah daerah masih belum jelas kepada masyarakat, yang mengakibatkan pengarahan dari pusat belum terlaksana dengan baik. Apabila sosialisasi tersebut dapat berjalan dan sudah sesuai dengan semestinya, pelayanan IMB akan berdampak terjadinya peningkatan pelayanan dan kesejahteraan masyarakat yang semakin baik, kehidupan demokrasi yang semakin maju, keadilan, pemerataan serta adanya hubungan yang serasi antara pusat dan daerah serta antardaerah.

\section{Coordinating (Pengoordinasian)}

Fungsi manajemen yang satu ini bertujuan untuk melakukan berbagai kegiatan-kegiatan agar tidak terjadi kekacauan serta menyatupadukan pekerjaan-pekerjaan bawahan sehingga terdapat kerja sama yang terarah dalam usaha mencapai tujuan bersama atau tujuan organisasi.

Namun, Jika berbicara mengenai koordinasi dalam pelayanan IMB, masyarakat sudah tidak lagi mendaftar manual ke Kecamatan maupun ke Kantor DPMPTSP Kabupaten Sumedang. Melainkan, diwajibkan mendaftar online. Hal ini sejalan dengan pendapat Abdul Somad Selaku Koordinator IMB di DPMPTSP sebagai berikut.

"Semua pelayanan yang ada di PTSP Sumedang itu sudah berbasis online jadi tidak ada lagi berkas-berkas hardcopy menumpuk di atas meja, sekarang semua pemohon menginput dan mengunggah (upload) berkas-berkas melalui sistem online dan sistem informasi yang kami namakan sistem infomasi SI ICE cetak mandiri disingkat SI ICE Mandiri. Itu aplikasi kan. Nah jadi, semua perizinan termasuk IMB itu masuk melalui sistem berkas-berkas itu semua dalam bentuk PDF di-scan semua, jadi si pemohon di mana pun bisa mendaftar ke kami melalui sistem dengan persyaratanpersyaratan tertentu." (14 Agustus 2020)

Berdasarkan wawancara di atas, jelaslah bahwa pendaftaran IMB sudah tidak lagi menggunakan daftar manual melainkan wajib daftar melalui perizinan online yang sudah disediakan aplikasinya oleh DPMPTSP.

\section{Controlling (Pengawasan)}

Pengawasan dimaksudkan di sini yaitu proses pemantauan yang dilakukan oleh tim pemungut retribusi IMB. Pengawasan dalam pelaksanaan pemungutan retribusi merupakan salah satu hal yang sangat penting. Pengawasan memegang peranan penting sebagai upaya dalam meminimalkan ketimpanganketimpangan dalam pemungutan retribusi. Pengawasan merupakan proses pemantauan yang dilakukan sebagai langkah untuk mengetahui apakah kegiatan pelaksanaan di lapangan sesuai dengan ketentuan, dengan pengawasan yang baik maka ketimpanganketimpangan yang dapat mengurangi keberhasilan pemungutan retribusi IMB dapat diminimalkan.

Demikian halnya dengan pemungutan retribusi IMB di Kecamatan Jatinangor yang dilakukan oleh DPMPTSP Kabupaten Sumedang menghindari menekan seminimal mungkin terjadinya penyimpanganpenyimpangan serta kesalahan lainnya yang mungkin terjadinya. Karena dalam pemungutan retribusi IMB di Kecamatan Jatinangor tanpa dilakukan pengawasan, 
maka akan mengalami kesulitan dalam mengukur tingkat keberhasilan yang dilaksanakan oleh para petugas yang melaksanakan pemungutan retribusi IMB di Kecamatan Jatinangor.

Hal ini sejalan dengan pendapat Diki selaku Kepala Seksi Penatausahaan Perizinan di DPMPTSP Kabupaten Sumedang sebagai berikut.

"Jadi mereka tuh masih ada paradigma bahwa bikin izin susah. Mereka lebih cenderung mempercayakan izin ke orang atau ke calo. Terlepas dari mana-mananya kan itu kan di luaran banyak yang mengaku dirinya bisa dan memproses izin. Nah paradigma seperti itu teh masih ada di dalam masyarakat. Jadi orang mempercayakan izinnya ke salah satu orang lagi. Sebenarnya, kalau sendiri itu mudah asal tau persyaratan dan caranya. Karena dampaknya memakai calo ya biaya makin besar." (14 Agustus 2020)

Dari hasil wawancara di atas penulis menyimpulkan bahwa pengawasan untuk bidang pemungutan retribusi IMB belum optimal. Hal ini terlihat masih ditemukannya calo dalam proses pembuatan IMB. Selain itu pun mengakibatkan masyarakat menjadi enggan untuk membuat IMB karena harus membayar dua kali lipat.

\section{Faktor Penghambat dalam Pengelo- laan Retribusi IMB}

\section{- Sumber Daya Manusia yang Belum Sesuai}

Dalam pelaksanaan pemungutan terhadap retribusi IMB di Kecamatan Jatinangor masih mengalami berbagai hambatan, baik hambatan dari dalam yaitu pihak petugas pemungut retribusi maupun dari luar yakni pemohon IMB tersebut. Staf Kasi Pelayanan Umum Kantor Kecamatan Jatinangor, Budilatif menyatakan bahwa:
"Dari SDM sendiri kita kekurangan staf, dari semua yang memeriksa saya, menghitung saya, kalau pemohon di sini tidak begitu banyak, yang banyak konsultasi soal IMB mengenai masalah persyaratan apa saja. Kadang 1 bulan 15-20 pemohon, tapi kalau pemohon yang gagal belum bisa di proses." (15 Agustus 2020)

Untuk mengoptimalisasikan pemungutan retribusi IMB di Kecamatan Jatinangor maka pengelolaan retribusi tersebut harus berjalan secara efektif dan efisien, karena dengan pengelolaan yang baik akan menghasilkan pemungutan retribusi IMB yang optimal sebagai akibat dari efisiensi dan efektivitas pengelolaan retribusi IMB tersebut. Sehingga target penerimaan retribusi IMB dapat terealisasi sebagaimana yang dikemukakan oleh Kania selaku Staf Pengelola Retribusi di DPMPTSP bahwa:

"Sebenarnya untuk dikatakan pemungutan retribusi IMB di Kecamatan Jatinangor secara pribadi saya katakan sudah optimal, karena kita lihat bahwa setiap tahun penerimaan retribusi ini meningkat meskipun belum tercapai target. Tetapi kalau secara umum pemungutan retribusi IMB di Kecamatan Jatinangor dikatakan sebenarnya belum tercapai. Karena salah satu tolak ukur optimalnya pemungutan retribusi itu adalah tercapainya target setiap tahun, sedangkan kami masih naik turun targetnya."

Selanjutnya ia menambahkan bahwa:

“... tapi ya kami selaku petugas yang bertugas mengelola retribusi IMB sudah mencoba melakukan yang terbaik terutama memperbaiki hal-hal yang saya katakan tadi. Tapi hasilnya untuk di Kecamatan Jatinangor belum juga optimal." (14 Agustus 2020)

Dari hasil wawancara di atas, terlihat bahwa pemungutan Retribusi IMB di Kecamatan Jatinangor belum optimal 
walaupun di Kecamatan Jatinangor membuktikan paling banyak data pemohon IMB dia antara kecamatan-kecamatan lain di Kabupaten Sumedang ini. Namun para petugas DPMPTSP telah berusaha untuk memperbaiki hal-hal yang menjadi penunjang utama optimalnya pemungutan retribusi IMB.

\section{- Kurangnya Kesadaran Masyarakat}

Izin Mendirikan Bangunan merupakan salah satu bentuk pengendalian tata ruang kota. Keberhasilan dari pengendalian tersebut sangat ditentukan oleh peran serta masyarakat. Artinya apabila setiap masyarakat yang ingin membangun atau merehabilitasi bangunan rumahnya, maka dapat dikendalikan melalui peran serta masyarakat dalam mengurus IMB yang merupakan faktor yang sangat penting dalam pengendalian tata ruang kota. Hal ini juga sejalan dengan tanggapan Syarif Effendi selaku Camat Jatinangor:

"Kalau di sini, khususnya Jatinangor sudah mencapai $77,5 \%$. Artinya bagi bangunan bangunan yang didirikan baru. Ada yang bangunannya sudah lama tapi dia belum buat IMB, nah memang ada yang diproses itu namanya pemutihan. Nah retribusinya juga itu lebih ringan, ada juga sebagian emang masih belum. Nah, manakala dia dibutuhkan baik itu untuk proses biasanya kredit ke bank itu untuk persyaratan IMB nah mereka baru buat. yah sekitar 75\% mah sudah." (5 Agustus 2020)

Melanjutkan pernyataan di atas, salah satu warga Kecamatan Jatinangor juga menambahkan bahwa:

"Ya begitulah, belum punya IMB karena masalah faktor biaya sama prosedur aja yang bikin ribet dan berbelit-belit".

Pernyataan di atas tersebut mengindikasikan bahwa masih ada masyarakat yang tidak memiliki IMB meskipun memiliki rumah tinggal, karena mereka masih beranggapan bahwa izin tersebut tidak ada manfaatnya. Selain itu juga salah satu faktor penyebab belum efektifnya pemberian IMB ialah kurangnya taraf kesadaran dan kepatuhan hukum masyarakat. Itu semua semakin memperjelas bahwa kesadaran masyarakat dibutuhkan untuk mendukung program-program Pemerintah, termasuk juga IMB. Padahal IMB merupakan kewajiban setiap orang yang memiliki bangunan, baik itu rumah tinggal maupun bangunan komersial.

Pendapat ini diperkuat dalam wawancara dengan Abdul Somad selaku Koordinator IMB di DPMPTSP yang mana:

"Jadi mereka tuh masih ada paradigma bahwa bikin izin susah. Mereka lebih cenderung mempercayakan izin ke orang atau ke calo. Terlepas dari mana-mananya kan itu kan di luaran banyak yang mengaku dirinya bisa dan memproses izin. Nah paradigma seperti itu teh masih ada di dalam masyarakat. Jadi orang mempercayakan izinnya ke salah satu orang lagi. Sebenarnya, kalau sendiri itu mudah asal tau persyaratan dan caranya. Karena dampaknya memakai calo ya biaya makin besar." (14 Agustus 2020)

Berdasarkan wawancara di atas penulis menyimpulkan bahwa ditemukannya calo dalamsebuah proseskepengurusan dibuatnya IMB, karena masih terdapatnya masyarakat yang belum mengerti dalam menggunakaan teknologi yang mengharuskan warga mendaftar IMB secara online. Sehingga adanya calo ini mengakibatkan masyarakat harus mengeluarkan uang lebih agar dapat membayar calo tersebut untuk membantu masyarakat yang kurang mengerti untuk mendaftar IMB secara online.

Dengan kurangnya kesadaran masyarakat akan pentingnya mempunyai IMB membuat realisasi penerimaan retribusi IMB Kecamatan Jatinangor itu sendiri tidak sesuai yang direncanakan. 


\section{Faktor Pendukung dalam Pengelolaan Retribusi IMB}

\section{- Adanya Media Informasi yang Baik}

Informasi yang diberikan guna memberikan pengetahuan pada masyarakat mengenai hal-hal yang berkaitan dengan IMB yang ada di Kecamatan Jatinangor saat ini sudah tersedia dengan baik. Penyediaan informasi diberikan melalui website: https:// perizinan.sumedangkab.go.id/ptsp/. Selain itu juga, di dalam website tersebut diberikan tata cara untuk mendaftar IMB yang mudah dipahami oleh masyarakat.

\section{- Tersedianya para Pendamping untuk Membuat IMB Online}

Seperti yang dikatakan oleh Diki selaku Kepala Seksi Penatausahaan Perizinan di DPMPTSP Kabupaten Sumedang sebagai berikut.

"Selain itu upaya yang kami lakukan seperti yang terlihat di ujung sana banyak komputer itu diperuntukan untuk pendampingan, pendampingan dalam artian apabila ada pemohon yang memiliki atau mau dibantu dalam hal pendaftaran izin secara online-nya, itu kami ada loket pendampingan, dan itu disediakan." (14 Agustus 2020)

Berdasarkan pernyataan di atas, itu semua diperuntukan agar nantinya masyarakat yang belum mengerti teknologi bisa mengerti dan mandiri ke depannya untuk membuat IMB secara online.

\section{Strategi Pengelolaan Retribusi IMB dalam Upaya Meningkatkan PAD di DPMPTSP}

Ukuran keberhasilan pada realisasi pendapatan Retribusi IMB tersebut dapat dilihat dari realisasi pencapaian target dan tingkat kenaikan pendapatan dari penerimaan Retribusi IMB, dengan banyaknya faktor yang memengaruhi penerimaan Retribusi IMB, maka tercapainya target penerimaan Retribusi akan ditentukan oleh sejauh mana usaha yang dilakukan pemerintah daerah itu dengan cara intensif dan baik, maka apa yang diharapkan dapat terwujud.

Sebaliknya apabila tidak dilakukan secara intensif atau kurang mendapatkan perhatian dalam mengelola faktor-faktor yang memengaruhinya tersebut, maka penerimaan Retribusi IMB tidak akan tercapainya sebagaimana yang diharapkan.

Pemungutan retribusi IMB di Kecamatan Jatinangor Kabupaten belum Optimal. Oleh karena itu sangat diperlukan upaya-upaya pemerintah dalam meningkatkan pemungutan retribusi IMB. Yaitu memperbaiki hal-hal yang menjadi penghambat tidak optimalnya pemungutan. Sebagaimana yang dijelaskan oleh Kania selaku Staf Pengelola Retribusi IMB di DPMPTSP bahwa:

"Saya berusaha semaksimal mungkin untuk mengoptimalkan pemungutan retribusi. Salah satu di antaranya yaitu lebih memperketat proses pengawasan, baik pengawasan secara langsung ataupun pengawasan secara langsung. Dan lebih memfungsikan tim pengawas untuk membantu para koordinator retribusi agar tidak selalu mis komunikasi." (14 Agustus 2020)

Lain halnya yang dijelaskan oleh Budilatif Selaku Kasi Pelayanan di Kecamatan Jatinangor mengatakan bahwa:

"Kalau menurut saya upaya yang harus dilakukan pemerintah guna untuk meningkatkan pemungutan retribusi yaitu meningkatkan tingkat ketegasan dalam pengawasan, pemberian sanksi bagi para petugas dan objek retribusi yang melakukan kesalahan dan diatur dalam peraturan daerah, perlunya aturan dalam Perda." (30 Agustus 2020).

Dari hasil wawancara di atas penulis menyimpulkan bahwa upaya-upaya untuk 
meningkatkan retribusi IMB, dalam hal ini hambatan pelaksanaan pemungutan retribusi harus dicari solusi agar pelaksanaan retribusi IMB dapat berjalan dengan lancar sesuai yang direncanakan, sehingga diperoleh pendapatan retribusi IMB sesuai yang ditargetkan. Bahkan kalau bisa melebihi target tersebut serta di peroleh peningkatan penerimaan retribusi dari waktu ke waktu. Untuk mengatasi hambatan-hambatan tersebut di atas, DPMPTSP Kabupaten Sumedang telah melakukan upaya-upaya sebagai berikut.

\section{- Sosialisasi}

Untuk menumbuhkan kesadaran masyarakat atau wajib retribusi IMB tentang pentingnya membayar retribusi, maka Dinas Penanaman Modal pelayanan Terpadu Satu Pintu telah mengadakan sosialisasi Peraturan Daerah tentang Retribusi IMB. Yakni melalui penyuluhan-penyuluhan secara langsung dan tidak langsung kepada wajib retribusi. Dengan penyuluhan ini diharapkan masyarakat mengerti tentang hak dan kewajiban sebagai wajib retribusi.

\section{- Pemutihan IMB}

Peraturan Menteri Dalam Negeri No. 32 Tahun 2010 menjelaskan bahwa Pemutihan ialah pemberian IMB terhadap bangunan yang sudah terbangun di kawasan yang belum memiliki RDTRK, RTBL, dan/atau RTRK. Pemutihan IMB di Kecamatan Jatinangor diatur dalam Peraturan Daerah Kabupaten Sumedang No. 5 Tahun 2011. Aturan ini terbit dengan maksud untuk meningkatkan pelayanan perizinan kepada masyarakat dan bertujuan untuk mewujudkan kesadaran masyarakat dalam hal kepemilikan IMB. Hal ini juga sesuai dengan pernyataan Budilatif, Kepala Seksi Pelayanan berikuit ini.

"Masyarakat yang tidak mampu membayar diberikan keringanan, yang diistilahkan pemutihan, gambar tidak dibuat, biaya berkurang 50\%." (15 Agustus 2020)
Pemutihan IMB sangat membantu Pemerintah Kabupaten Sumedang khususnya di Kecamatan Jatinangor dalam hal pencapaian target pendapatannya, karena usaha ini dapat menjaring bangunan-bangunan yang tidak memiliki Izin. Namun Pemutihan ini memiliki kriteria-kriteria yang membatasi ruang lingkup berlakunya, misalnya kriteria rumah tinggal dengan pembatasan luas bangunan yang tidak lebih dari $150 \mathrm{~m} 2$ meskipun pemilik bangunan tersebut berpenghasilan rendah, karena pada dasarnya Pemutihan diberikan untuk masyarakat berpenghasilan rendah.

Hal ini sesuai dengan pernyataan Diki selaku Koordinator IMB di DPMPTSP ketika ditanya mengenai bangunan lama yang belum memiliki IMB dan tidak mampu mengurus/membayar:

"Kami punya upaya, kami melakukan Pemutihan, kriteria Pemutihan IMB itu: Diberikan kemudahan kepada masyarakat berpenghasilan rendah." (14 Agustus 2020)

Hal ini juga merupakan usaha untuk memudahkan masyarakat dalam melakukan pembayaran retribusi IMB-nya, sehingga biaya yang cukup besar tersebut bisa menjadi ringan dengan pembayaran yang bertahap. Namun ketentuan mengenai lama angsuran dalam pemberian keringanan retribusi IMB ini belum dibentuk, sehingga belum dapat diketahui seberapa besar hasilnya dalam meningkatkan realisasi retribusi IMB.

\section{- Peningkatan Pengawasan}

Agar dalam melaksanakan pemungutan retribusi IMB dapat berjalan dengan baik, Dinas Penanaman Modal Pelayanan Terpadu Satu Pintu telah melaksanakan pengawasan secara langsung terhadap pelaksanaan retribusi. Dengan demikian diharapkan para petugas pungut melaksanakan tugasnya dengan baik agar retribusi IMB dapat mencapai target tiap tahunnya. 
Selanjutnya, upaya mengatasi permasalahan Pengelolaan Retribusi IMB dalam meningkatkan PAD di Kecamatan Jatinangor Kabupaten Sumedang yaitu dengan memperhatikan lingkungan internal yang berupa kekuatan ataupun kelemahan dan lingkungan eksternal yang berupa peluang maupun ancaman. Dengan menggunakan matriks SWOT akan ditentukan isu strategis yang perlu ditangani oleh Dinas Penanaman Modal Pelayanan Terpadu Satu Pintu Kabupaten Sumedang.

Berdasarkan hasil analisis SWOT pada matriks Tabel 5 diperoleh beberapa isu strategis sebagai berikut.

\section{1) Strategi $S-0$}

Strategi ini bersumber dari Strengths dan Opportunities. Strategi S-O ini diciptakan dengan menggunakan kekuatan untuk memanfaatkan peluang yang ada. Strategi yang harus diterapkan dalam kondisi ini memanfaatkan wilayah, karena sebagai Kawasan Strategis Pendidikan dalam meningkatkan pembangunan daerah.

\section{2) Strategi S-T}

Strategi yang bersumber dari Strengths dan Threats ini merupakan strategi yang diciptakan dengan menggunakan kekuatan dari lingkungan internal untuk mengatasi ancaman yang berasal dari lingkungan eksternal. Meskipun menghadapi ancaman, organisasi masih memiliki kekuatan secara internal. Strategi yang harus diterapkan adalah menggunakan Memanfaatkan media informasi yang baik untuk meningkatkan jumlah wajib IMB.

\section{3) Strategi $\mathbf{W}-0$}

Srategi yang bersumber dari Weakness dan Opportunities ini merupakan sebuah strategi yang diciptakan

Tabel 5 Hasil Matriks Analisis SWOT

\begin{tabular}{|c|c|c|}
\hline R EKSTERNAL & $\begin{array}{l}\text { STRENGTHS (S) } \\
\text { 1. Media informasi yang baik, } \\
\text { yaitu tersedianya website di } \\
\text { dinas. } \\
\text { 2. Tersedianya para Pendamping } \\
\text { untuk membuat IMB online } \\
\text { bagi yang belum mengerti } \\
\text { teknologi. }\end{array}$ & $\begin{array}{l}\text { WEAKNESSES (W) } \\
\text { 1. Sumber daya manusia yang } \\
\text { belum sesuai. } \\
\text { 2. Kurangnya kesadaran } \\
\text { masyarakat. } \\
\text { 3. Kurangnya sosialisasi wajib } \\
\text { IMB kepada Masyarakat. } \\
\text { 4. Adanya Calo dalam proses } \\
\text { pembuatan IMB }\end{array}$ \\
\hline OPPORTUNITIES (0) & STRA & I $W-0$ \\
\hline $\begin{array}{l}\text { 1. Sebagai Kawasan Strategis } \\
\text { Pendidikan. } \\
\text { 2. Adanya Peraturan Daerah } \\
\text { tentang IMB dan Retribusi } \\
\text { Perizinan Tertentu yang } \\
\text { mendukung. }\end{array}$ & $\begin{array}{l}\text { Memanfaatkan wilayah, karena } \\
\text { sebagai Kawasan Strategis } \\
\text { Pendidikan dalam meningkatkan } \\
\text { pembangunan daerah. }\end{array}$ & $\begin{array}{l}\text { 1. Pemutihan IMB. } \\
\text { 2. Meningkatkan Pengawasan } \\
\text { terhadap adanya Calo }\end{array}$ \\
\hline $\begin{array}{l}\text { THREATS (T) } \\
\text { 1. Kurangnya Wajib IMB. } \\
\text { 2. Kurangnya kesadaran } \\
\text { masyarakat wajib IMB. } \\
\end{array}$ & $\begin{array}{l}\text { STRATEGI S - T } \\
\text { Memanfaatkan media informasi } \\
\text { yang baik untuk meningkatkan } \\
\text { jumlah wajib IMB. }\end{array}$ & $\begin{array}{l}\text { STRATEGI W - T } \\
\text { Meningkatkan sosialisasi agar } \\
\text { masyarakat patuh dan wajib IMB. }\end{array}$ \\
\hline
\end{tabular}

Sumber: Data diolah Penulis 
dengan meminimalkan kelemahan untuk memanfaatkan peluang. Mendukung strategi turnaraound (putar balik), dalam artian mengambil beberapa langkah untuk mengatasi berbagai kelemahan yang dihadapi secara internal agar peluang dapat dimanfaatkan. Strategi W-O yang diambil adalah diberikannya Pemutihan IMB serta Meningkatkan Pengawasan dalam Retribusi IMB.

\section{4) Strategi W-T}

Strategi yang bersumber dari Weakness dan Threats ini merupakan sebuah strategi yang diciptakan dengan meminimalkan kelemahan dan menghindari ancaman. Kelemahan yang bersumber dari lingkungan internal kemudian diminimalkan dan juga digunakan untuk menghindari ancaman dari lingkungan eksternal. Ini merupakan kondisi yang sangat tidak menguntungkan, organisasi mengalami berbagai ancaman dan kelemahan internal. Strategi yang mendukung adalah Meningkatkan sosialisasi agar masyarakat patuh dan wajib IMB. Karena melalui sosialisasi masyarakat akan paham betapa pentingnya mempunyai IMB.

Berdasarkan kelima isu strategis seperti tampak pada Tabel 6, kemudian tahapan selanjutnya yaitu merumuskan programprogram strategis dalam mengoptimalkan
Pengelolaan Retribusi IMB dalam meningkatkan PAD di DPMPTSP Kabupaten Sumedang Provinsi Jawa Barat (Studi Pada Kecamatan Jatinangor Kabupaten Sumedang Provinsi Jawa Barat).

Dalam perumusan program-program strategis ini, diperlukan kerja sama yang baik antara pemerintah daerah dan masyarakat. Berikut adalah rincian perumusan programprogram strategisnya:

1. Isu Strategis, meliputi:

a. Memanfaatkan wilayah, karena sebagai kawasan strategis pendidikan dalam meningkatkan pembangunan daerah.

b. Memanfaatkan media informasi yang baik untuk meningkatkan jumlah wajib IMB.

c. Pemutihan IMB serta meningkatkan pengawasan.

d. Meningkatkan sosialisasi agar masyarakat patuh dan wajib IMB.

2. Isu Moderat, meliputi:

- Meningkatkan pengawasan terhadap adanya Calo.

\section{SIMPULAN}

Berdasarkan hasil penelitian dan pembahasan, maka dapat penulis disimpulkan ke dalam beberapa poin sebagai berikut.

Tabel 6 Klasifikasi Isu-Isu Strategis

\begin{tabular}{|c|c|c|c|}
\hline No & Isu Strategis Total Skor Sifat Isu & Total Skor & Sifat Isu \\
\hline 1 & $\begin{array}{l}\text { Memanfaatkan wilayah, karena sebagai Kawasan Strategis Pendidikan } \\
\text { dalam meningkatkan pembangunan daerah. }\end{array}$ & 34 & Strategis \\
\hline 2 & $\begin{array}{l}\text { Memanfaatkan media informasi yang baik untuk meningkatkan jumlah } \\
\text { wajib IMB. }\end{array}$ & 33 & Strategis \\
\hline 3 & Pemutihan IMB serta Meningkatkan Pengawasan. & 33 & Strategis \\
\hline 4 & Meningkatkan Pengawasan terhadap adanya Calo & 29 & Moderat \\
\hline 5 & Meningkatkan sosialisasi agar masyarakat patuh dan wajib IMB. & 34 & Strategis \\
\hline
\end{tabular}

Sumber: Data Tes Litmus yang diolah 
1. Pengelolaan Retribusi IMB dalam meningkatkan PAD di DPMPTSP Kabupaten Sumedang (Studi Pada Kecamatan Jatinangor Kabupaten Sumedang) dapat dikatakan belum optimal. Karena ditemukannya ketidaksiapan masyarakat akan penerapan sistem pendaftaran IMB secara online. Selain itu pun sosialisasi yang diberikan oleh pemerintah kepada masyarakat sangatlah minim yang menyebabkan mengapa target realisasi penerimaan retribusi Izin Mendirikan Bangunan (IMB) dalam tiga tahun ke belakang selalu menurun.

2. Terdapat beberapa faktor penghambat danfaktor pendukung dalam Pengelolaan Retribusi IMB dalam meningkatkan PAD di DPMPTSP Kabupaten Sumedang (Studi pada Kecamatan Jatinangor Kabupaten Sumedang) ini. Pertama, adanya faktor penghambat meliputi sumber daya manusia yang bekerja tidak sesuai tupoksinya, serta kurangnya kesadaran masyarakat. Kedua, faktor pendukung yang meliputi adanya media informasi yang baik, tersedianya para pendamping untuk membuat IMB online bagi yang belum mengerti teknologi.

3. Strategi yang sebaiknya harus digunakan oleh pemerintah daerah adalah sebagai berikut. (1) Dilakukannya Pemutihan IMB serta meningkatkan pengawasan dalam retribusi IMB yang meliputi, mempermudah masyarakat dalam persyaratan membuat IMB baru maupun IMB lama serta memberikan retribusi dengan harga yang tidak tinggi. (2) Memanfaatkan media informasi yang baik untuk meningkatkan jumlah wajib IMB yakni menggunakan website sebagai sarana memberikan informasi mengenai pentingnya wajib IMB serta memberikan alur pendaftaran yang baik dan mudah dimengerti untuk masyarakat juga penerapan asas pengelolaan keuangan yang baik yaitu efektif, efisien, dan transparan untuk meningkatkan kepercayaan dari investor. (3) Memanfaatkan wilayah, karena sebagai kawasan strategis pendidikan dalam meningkatkan pembangunan daerah yang meliputi, pemerintah daerah harus bisa mengendalikan perizinan yang sesuai dengan peruntukannya agar tidak terjadi adanya pembangunan secara liar dan menjadi acuan sebagai bahan contoh yang baik untuk pemerintah daerah yang lain. (4) Meningkatkan sosialisasi agar masyarakat patuh dan wajib IMB yang meliputi, diberlakukannya sosialisasi minimal ke setiap Kecamatan satu bulan sekali serta mengadakan kerja sama yang baik dengan masyarakat sekitar.

\section{SARAN}

Berdasarkan simpulan di atas, maka penulis memberikan saran sebagai bahan evaluasi dan masukan terkait Pengelolaan Retribusi Izin Mendirikan Bangunan (IMB) dalam meningkatkan Pendapatan Asli Daerah (PAD) di Dinas Penanaman Modal dan Pelayanan Terpadu Satu Pintu Kabupaten Sumedang Provinsi Jawa Barat (Studi pada Kecamatan Jatinangor Kabupaten Sumedang Provinsi Jawa Barat) sebagai berikut.

1. Meningkatkan peran serta pihak Kecamatan di masing-masing wilayah Kecamatan Jatinangor dalam menyelenggarakan perizinan IMB rumah tinggal dan nonrumah tinggal dalam rangka meningkatkan Retribusi IMB.

2. Menambah Sumber daya aparatur (SDM) khususnya tenaga lapangan. Dengan harapan masing-masing wilayah memiliki 1 orang tenaga lapangan yang bertanggung jawab terhadap masyarakat yang mengurus IMB.

3. Meningkatkan pemahaman masyarakat tentang betapa wajib dan pentingnya manfaat IMB bagi peningkatan kesejahteraan masyarakat dan wilayah sekitar. 


\section{DAFTAR RUJUKAN}

Bryson, Jhon M. (2007). Perencanaan Strategis Bagi Organisasi Sosial Yogyakarta: Pustaka Pelajar.

Gulo, W. (2007). Metodologi Penelitian. Jakarta: Grasindo.

Nawawi, Hadari. (2005). Manajemen Sumber Daya Manusia Untuk Bisnis yang Kompetitif. Yogyakarta: Gajah Mada University Press Anggota IKAPI. hal. 42.

Nawawi, Hadari. (2012). Metode Penelitian Bidang Sosial. Yogyakarta: Gajah Mada University Press.

Hasibuan, Malayu. (2008). Manajemen Dasar, Pengertian, Dan Masalah. Jakarta: PT Bumi Aksara.

Nazir, Mohammad,Ph.D. (2011). Metode Penelitian. Jakarta: Ghalia Indonesia.

Rangkuti, Freddy. (2014). SWOT Balanced Scorecard. Jakarta: PT Gramedia Pustaka Utama.

Renyowijoyo, Muindro. (2013). Akuntansi Sektor Publik Organisasi Nir Laba. Jakarta: Mitra Wacana Media.

Siregar, Doli. (2004). Manajemen Aset. Jakarta: Satyatama Graha Tara.

Sugiyono. (2013). Metode Penelitian Pendidikan Pendekatan Kuantitatif, Kualitatif, dan $R \& D$. Bandung: Alfabeta.

Sutedi, Adrian. (2015). Hukum Perizinan Dalam Sektor Pelayanan Publik. Jakarta: Sinar Grafika.

Sondang P.Siagian. (2000). Manajemen Stratejik. Jakarta: PT Bumi Aksara.

Terry, George R. (2009). Prinsip-prinsip Manajemen. Jakarta: Penerbit Bumi Aksara.

Warsito. (2001). Hukum Pajak. Jakarta: PT Rajawali Grafindo Persada.

Zuriah, Nuzul. (2009). Metodologi Penelitian Sosial Pendidikan Teori-Aplikasi. Jakarta: PT Bumi Aksara.
Tesis

Martani Setyawati. 2010. Analisis Pengaruh Penerimaan Retribusi Daerah terhadap Pendapatan Asli Daerah Kabupaten Sragen.

Irfansyah. 2015. Studi tentang Kontribusi Penerimaan Retribusi Izin Mendirikan Bangunan (IMB) Dalam Peningkatan Pendapatan Asli Daerah (PAD) Di Kabupaten Penajam Paser Utara.

Syska Lady Sulistyowatie. 2016. Pengaruh Penerimaan Pajak Daerah dan Retribusi Daerah terhadap Peningkatan Pendapatan Asli Daerah (PAD) Kabupaten Klaten.

\section{Jurnal}

Fernandes Simangunsong. 2015. Studi Evaluasi Penetapan Pendapatan Retribusi IMB Kecamatan di Kabupaten Bandung.

Anwar Ramli. 2016. Analisis Faktor-faktor yang Memengaruhi Pendapatan Asli Daerah di Kabupaten Bone.

Azwir Nasir, Yesi Mutia Basri, Kamaliah, Iskandar Muda. 2017. Efektivitas Potensi Pajak Daerah sebagai Sumber Pendapatan Asli Daerah di Riau Area Pesisir.

Suprihati, LM Kristiyanti, Hajir. 2018. Meningkatkan Penghasilan Asli Daerah dengan Penerimaan Pajak, Retribusi Regional dan Hasil Pengelolaan Kekayaan Regional di Solo Raya.

\section{Peraturan Perundang-Undangan}

Peraturan Daerah Kabupaten Sumedang No. 5 Tahun 2011 tentang Retribusi Perizinan Tertentu.

Peraturan Daerah Kabupaten Sumedang No. 15 Tahun 2011 tentang Bangunan Gedung.

Peraturan Bupati Sumedang No. 30 Tahun 2017 tentang Pendelegasian sebagian Kewenangan di Bidang Perizinan dan Non-perizinan dari Bupati Kepada Kepala Dinas Penanaman Modal Dan Pelayanan Terpadu Satu Pintu. 
Virioner - Vol. $13 \backslash$ No. $1 \backslash$ April 2021: 41-58

\section{Website}

Bappenda Kabupaten Sumedang https://

bappenda.sumedangkab.go.id/ infografis/

DPMPTSP Kabupaten Sumedang https://

perizinan.sumedangkab.go.id/ptsp/ 